\title{
(D) Gamma heavy chain disease complicated by OPEN ACCESS pulmonary hypertension, which was successfully treated with lenalidomide
}

\author{
Sho Shibata, Akiko Fukunaga
}

Hematology, Tazuke Kofukai, Medical Research Institute, Kitano Hospital, Osaka, Japan

\section{Correspondence to}

Dr Sho Shibata;

ashitaharerukana21@gmail.com

Accepted 2 November 2020

\section{Check for updates}

(c) BMJ Publishing Group Limited 2020. Re-use permitted under CC BY-NC. No commercial re-use. See rights and permissions. Published by BMJ.

To cite: Shibata S, Fukunaga A. BMJ Case Rep 2020;13:e236162 doi:10.1136/bcr-2020236162

\section{SUMMARY}

Heavy chain disease (HCD) is a rare B-cell proliferative neoplasm that is characterised by the production of truncated monoclonal immunoglobulin heavy chains without light chains. Gamma HCD is a subgroup of HCD. A 67-year-old man was admitted to our hospital with dyspnoea and lower leg oedema. Based on the results of heart catheterisation, he was diagnosed with pulmonary hypertension. Laboratory tests revealed an elevated level of $\mathrm{IgG}$, and serum immunoelectrophoresis showed that IgG was a monoclonal gamma heavy chain without light chains. Finally, he was diagnosed with gamma HCD complicated by pulmonary hypertension. Bortezomib and dexamethasone therapy was initiated, but became refractory within 8 months. Therefore, the treatment was switched to lenalidomide and dexamethasone therapy, and the disease has been stably controlled for more than 2 years. To the best of our knowledge, this is the first case of gamma HCD being successfully treated by lenalidomide and dexamethasone therapy.

\section{BACKGROUND}

Heavy chain disease (HCD) is a rare B-cell proliferative neoplasm that is characterised by the production of truncated monoclonal immunoglobulin heavy chains without light chains. HCD has been divided into three categories based on the type of monoclonal heavy chain isotype $(\alpha, \gamma$ and $\mu){ }^{1}$ Gamma HCD, also known as Franklin's disease, was initially reported by Franklin et al in 1964, and is a very rare disease; only approximately 150 cases have been reported to date. ${ }^{3}$ Tumour cells are assumed to be derived from postgerminal centre B cells with the ability to differentiate into plasma cells. ${ }^{3}$ The tumour cells of gamma HCD typically involve the lymph nodes, bone marrow, liver, spleen, peripheral blood and other extranodal sites. Involved tissues generally show the polymorphous proliferation of lymphocytes, plasmacytoid lymphocytes and plasma cells. ${ }^{4}$ Most patients present with systemic symptoms, lymphadenopathy and splenomegaly. Almost $25 \%$ of patients have a history of autoimmune disease, such as rheumatoid arthritis, autoimmune haemolytic anaemia or thrombocytopenic purpura. ${ }^{56}$ Several studies have reported the diversity of the clinical manifestations and haematopathological features of gamma HCD, and its clinical course varies, ranging from indolent to progressive.

There is currently no standard therapy for gamma HCD, and some cases have been treated with chemotherapy using the cyclophosphamide, vincristine and prednisone (CVP regimen), cyclophosphamide, vincristine, doxorubicin and prednisone (CHOP regimen), melphalan and bortezomib. Lenalidomide, an immunomodulatory drug (IMiD), has not yet been used in the treatment of gamma HCD. We herein present a case of gamma HCD complicated by pulmonary hypertension that showed a clinical response to lenalidomide.

\section{CASE PRESENTATION}

A 67-year-old man was admitted to our hospital with dyspnoea and lower leg oedema for 1 month. He had a history of type 2 diabetes. On examination, his blood pressure was $163 / 88 \mathrm{~mm} \mathrm{Hg}$, pulse $97 / \mathrm{min}$ and respiratory rate $26 / \mathrm{min}$ with an $\mathrm{O}_{2}$ saturation of $88 \%$ in room air, and he had splenomegaly and no palpable lymphadenopathy. X-ray of the chest revealed an elevated cardiothoracic ratio of $65 \%$. Echocardiography showed an elevated tricuspid regurgitation pressure gradient (TRPG) of $75 \mathrm{~mm} \mathrm{Hg}$, and, thus, right heart catheterisation was performed. The examination revealed a mean pulmonary artery pressure of $54 \mathrm{~mm} \mathrm{Hg}$, and pulmonary artery wedge pressure (PAWP) of $18 \mathrm{~mm}$ $\mathrm{Hg}$, which was consistent with pulmonary hypertension. Treatment was initiated with a phosphodiesterase 5 inhibitor and prostacyclin analogue; however, no improvements were observed.

\section{INVESTIGATIONS}

Laboratory tests indicated an elevated level of IgG $(4850 \mathrm{mg} / \mathrm{dL})$ and he was referred to our department. Other laboratory data showed a white blood cell count of $3.0 \times 10^{9} / \mathrm{L}$, haemoglobin level of 92 $\mathrm{g} / \mathrm{L}$, platelet count of $79 \times 10^{9} / \mathrm{L}$, lactate dehydrogenase level of $343 \mathrm{IU} / \mathrm{L}$, serum creatinine level of $0.88 \mathrm{mg} / \mathrm{dL}$ and interleukin-2 receptor level of $983 \mathrm{U} / \mathrm{mL}$. There were no tumour cells in his peripheral blood. His serum IgA level decreased to $64 \mathrm{mg} / \mathrm{dL}$, his IgM level was normal $(48 \mathrm{mg} / \mathrm{dL})$ and the serum-free light chain ratio $(\kappa / \lambda)$ was normal. Serum protein electrophoresis revealed the presence of the $\mathrm{M}$ protein (figure 1). In serum immunoelectrophoresis, serum formed an M-bow in response to anti-IgG antiserum, but not in response to anti- $\kappa$ antiserum or anti- $\lambda$ antiserum. Serum also formed an M-bow in response to anti-IgG Fc antiserum. (figure 2) Bence Jones protein was not detected by urine immunoelectrophoresis. Bone marrow aspiration showed approximately $10 \%$ abnormal plasmacytoid cells (figure 3), and bone marrow biopsy 


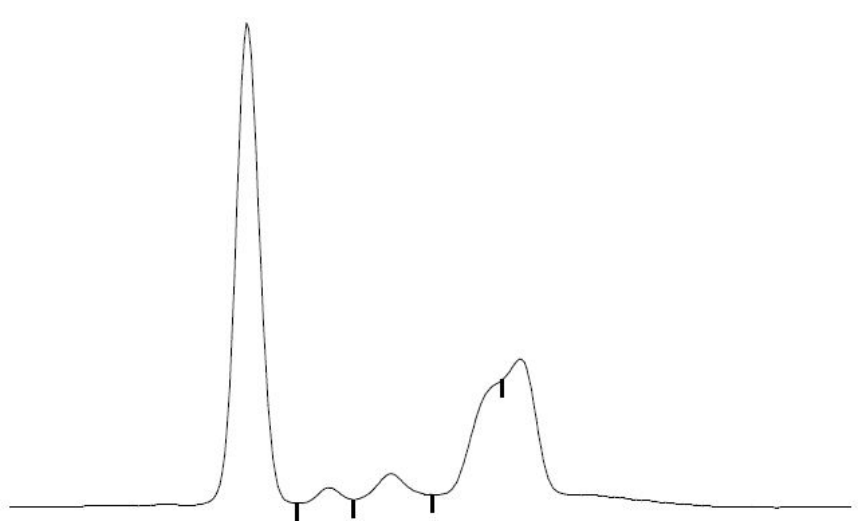

Figure 1 Serum protein electrophoresis revealed the presence of the $\mathrm{M}$ protein in $\beta$ and $\gamma$ fractions. The shape of the $M$ peak was not typical.

revealed that cells expressed CD138, but not kappa or lambda chains (figure 4). A flow cytometric analysis of bone marrow revealed no population with cytoplasmic immunoglobulin light chain restrictions in the lymphocyte fraction. A PCR analysis and Southern blotting demonstrated a clonal rearrangement of the immunoglobulin heavy-chain gene (figure 5). No cytogenetic abnormality was indicated in G-banding. CT revealed splenomegaly and no lymphadenopathy. No fluorodeoxyglucose (FDG) uptake was observed on whole-body positron emission tomography $(\mathrm{PET}) / \mathrm{CT}$.

\section{TREATMENT}

The patient was diagnosed with gamma HCD complicated by pulmonary hypertension (group 5, pulmonary hypertension due to unclear multifactorial mechanisms, according to the Nice classification). ${ }^{7}$

The patient was started on BD therapy (bortezomib $1.3 \mathrm{mg} /$ $\mathrm{m}^{2} /$ day on days $1,4,8$ and 11 , and dexamethasone $20 \mathrm{mg} /$ day on days $1,2,4,5,8,9,11$ and 12). After the initiation of BD

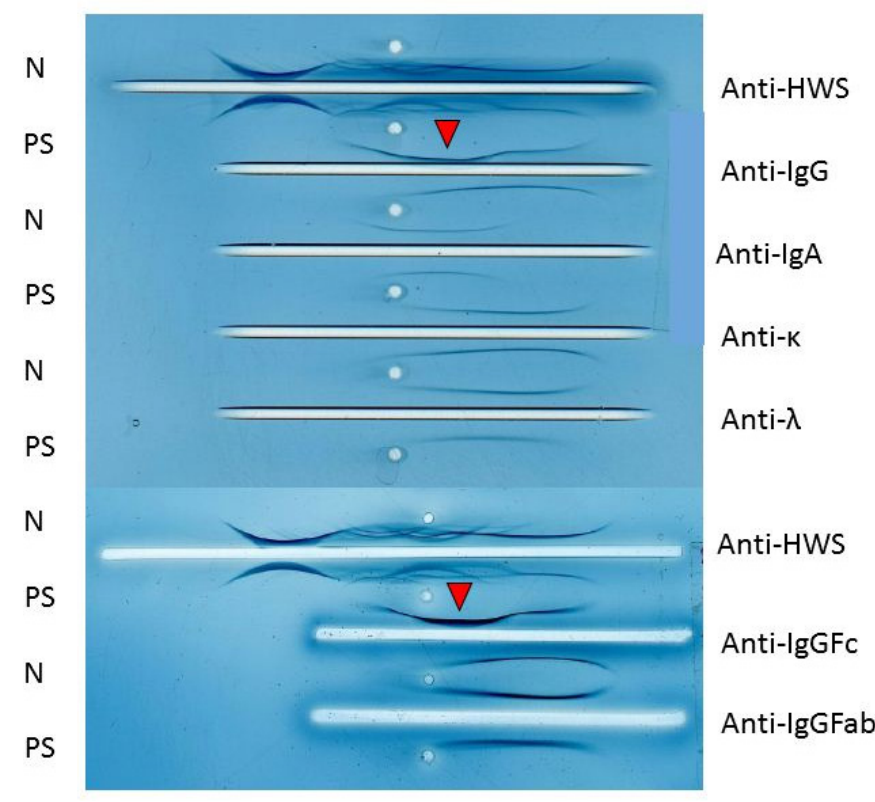

Figure 2 In serum immunoelectrophoresis, serum formed an M-bow in response to anti-IgG antiserum, but not to anti- $\kappa$ antiserum or anti- $\lambda$ antiserum. in addition, serum formed an M-bow in response to anti-lgG Fc antiserum. N, normal serum; PS, patient's sample.

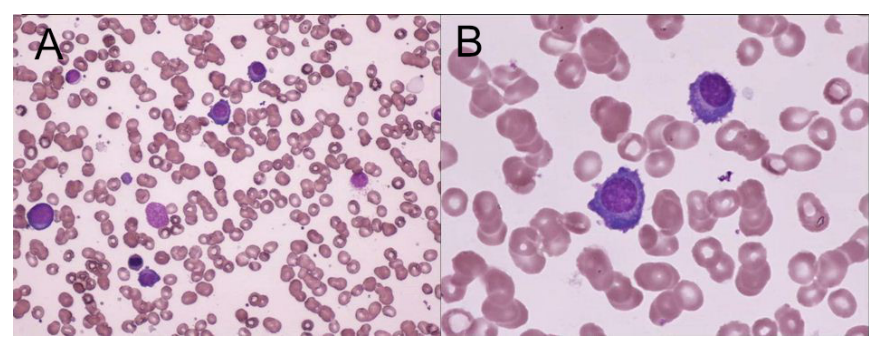

Figure 3 The bone marrow aspirate contained approximately $10 \%$ abnormal plasmacytoid cells. (A) May Giemsa staining, $\times 200$. (B ) May Giemsa staining, $\times 1000$.

therapy, his serum IgG level and TRPG immediately decreased with the attenuation of clinical manifestations. However, after eight cycles of BD therapy, his IgG level increased to $2500 \mathrm{mg} /$ $\mathrm{dL}$. We decided that BD therapy became refractory and switched the treatment to RD therapy (lenalidomide $25 \mathrm{mg} /$ day on days 1-21, dexamethasone $20 \mathrm{mg} /$ day on days 1, 8, 15 and 22). RD therapy successfully decreased his serum IgG level to the normal range, along with TRPG of $14 \mathrm{~mm} \mathrm{Hg}$. After RD therapy, the $\mathrm{M}$ protein was still detected by serum protein electrophoresis, whereas splenomegaly was attenuated and abnormal plasmacytoid cells disappeared from bone marrow. The patient developed grade 4 neutropaenia and grade 3 thrombocytopenia. Therefore, we reduced the dose of lenalidomide to $20 \mathrm{mg}$ /day from the fifth course of treatment. Despite grade 4 neutropaenia, no signs of infection were observed. He has been treated with RD therapy for 2 years on an outpatient basis with a stable disease status for gamma HCD and pulmonary hypertension (figure 6).

\section{DISCUSSION}

The patient did not present with systemic symptoms, lymphadenopathy, such as lymphoma, or autoimmune disease. The main symptoms were dyspnoea and oedema, which were caused by pulmonary hypertension. To the best of our knowledge, there has been no reported case of gamma HCD complicated by pulmonary hypertension. Pulmonary hypertension occurs in several haematological disorders, such as sickle cell disease, thalassemia and myeloproliferative neoplasms (MPN). ${ }^{8}$ In the Nice classification, pulmonary hypertension is classified into one of five groups based on its aetiology, with cases caused by haematological disorders being placed into group 5, pulmonary

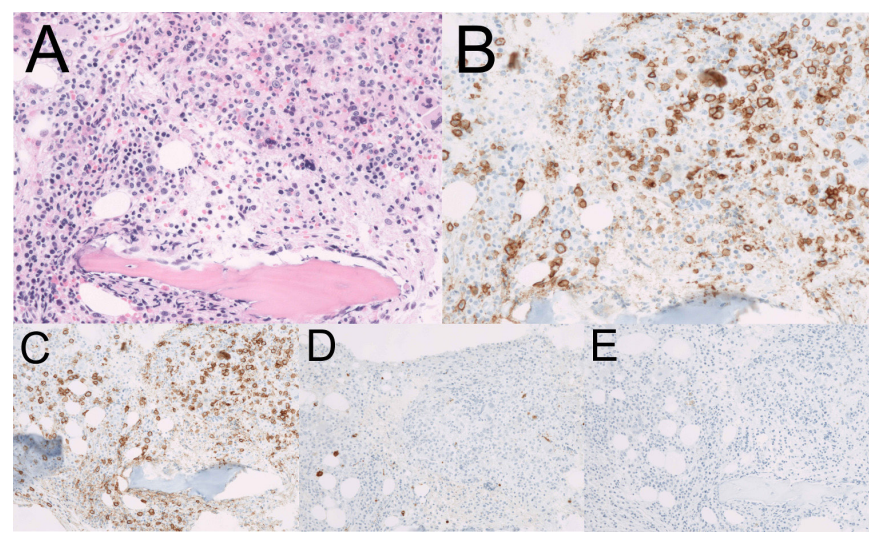

Figure 4 Pathology of bone marrow. Immunohistochemically, tumour cells were positive for CD138, and negative for kappa and lambda. (A) H\&E staining, $\times 400$. (B) CD138 staining, $\times 400$. (C) CD138 staining, $\times 200$. (D) lambda staining, $\times 200$. (E) kappa staining, $\times 200$. 


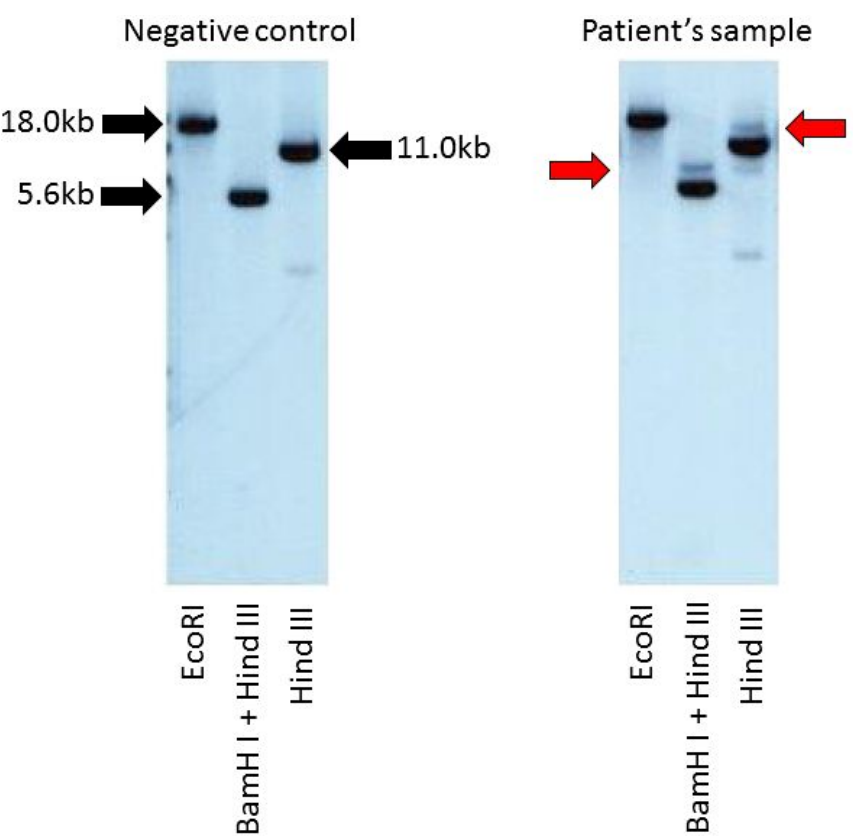

Figure 5 Southern blotting with an immunoglobulin heavy chain $\mathrm{JH}$ gene probe demonstrated the clonal rearrangement of the immunoglobulin heavy chain JH gene.

hypertension due to unclear multifactorial mechanisms. ${ }^{7}$ The pathology by which haematological disorders develop pulmonary hypertension remains unclear and multifactorial. In haemolytic disorders, one of the mechanisms is assumed to involve haemolysis, resulting in increased free haemoglobin, and significant reductions in NO bioavailability due to free haemoglobin developing endothelial dysfunction, which leads to pulmonary hypertension. ${ }^{9}$ In MPN, bone marrow-derived circulating cells may play an important role in its pathogenesis. ${ }^{10}$

Some cases of pulmonary hypertension are complicated by multiple myeloma, and the aetiology may not involve a single mechanism, but rather a combination of mechanisms, such as immunoglobulin light chain (AL) amyloid deposition, high cardiac output states, or renal disease. ${ }^{11} \mathrm{AL}$ amyloidosis often involves the heart, and elevated left atrial pressure may cause pulmonary hypertension. Furthermore, a previous case report of pulmonary hypertension was due to pulmonary vascular amyloid deposition in a patient with multiple myeloma. ${ }^{12}$ High

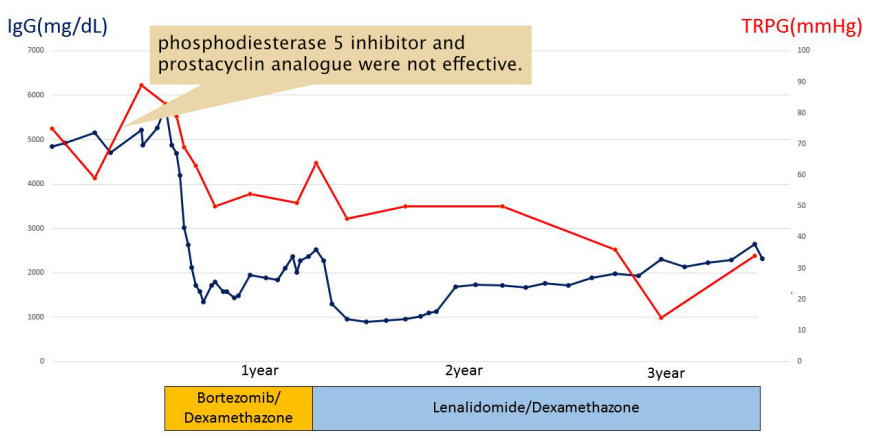

Figure 6 The clinical course. Bortezomib had a temporary effect, but became refractory within 8 months. Therefore, lenalidomide was administered. His serum IgG level and tricuspid regurgitation pressure gradient (TRPG) by echocardiography rapidly decreased, and the disease has been stably controlled for more than 2 years. The response to treatment was parallel in IgG and TRPG. cardiac output states also promote left atrial hypertension. Renal disease causes volume overload and secondary hypertension. In the present case, biopsy was not performed, PAWP was slightly elevated, and there was no serious renal impairment; therefore, the mechanisms responsible for pulmonary hypertension remained unclear. Since the response to treatment was parallel in gamma HCD and pulmonary hypertension, we presumed that pulmonary hypertension was affected by the pathological condition of gamma HCD.

Gamma HCD is a very rare and heterogeneous disease, for which there is currently no standard therapy. In some patients, the clinical course is indolent and observation may be a treatment option. Some reported cases have been successfully treated with chemotherapy using the CVP regimen, $\mathrm{CHOP}$ regimen, melphalan and prednisone. ${ }^{4513}$

Rituximab monotherapy and combination therapy were previously reported to be effective when tumours expressed CD20. ${ }^{14}$ A previous case of gamma HCD with plasma cell dyscrasia was shown to respond to treatment with bortezomib and dexamethasone. ${ }^{15}$ Bortezomib is a proteasome inhibitor that is used in the treatment of multiple myeloma and mantle cell lymphoma. In the present case, abnormal plasmacytoid cells involved the bone marrow; therefore, we initially attempted to treat the patient with bortezomib. Bortezomib had a temporary effect, but became refractory within 8 months. We then attempted to treat the patient with lenalidomide, which is classified as IMiD, and a derivative of thalidomide. Lenalidomide is a standard treatment for multiple myeloma, and the incorporation of lenalidomide improves the prognosis of multiple myeloma. Furthermore, its efficacy has been demonstrated for B-cell lymphoma, particularly mantle cell lymphoma, follicular lymphoma and non-germinal centre diffuse large B-cell lymphoma. ${ }^{16}$ After the administration of lenalidomide, serum protein electrophoresis detected the $\mathrm{M}$ protein; however, its level decreased and abnormal plasmacytoid cells disappeared from bone marrow. Lenalidomide was effective for not only gamma HCD, but also pulmonary hypertension. The only adverse events observed were grade 4 neutropaenia and grade 3 thrombocytopenia, which were ameliorated by a reduction in the dose of lenalidomide administered. The patient has been treated with RD therapy for 2 years on an outpatient basis with a stable disease status. In conclusion, to the best of our knowledge, this is the first case report of gamma HCD that demonstrated a clinical response to lenalidomide and dexamethasone therapy, and we concluded that lenalidomide has potential as an effective treatment option for this very rare disease. Moreover, this case was characteristic in that gamma HCD was complicated by pulmonary hypertension.

\section{Learning points}

Gamma heavy chain disease (HCD) is a rare B-cell proliferative neoplasm that is characterised by the production of truncated monoclonal immunoglobulin heavy chains without light chains.

- Lenalidomide has potential as an effective new treatment option for gamma HCD.

- Gamma HCD can cause pulmonary hypertension.

Contributors AF was attending physician. SS analysed test results and literature and was involved in the treatment. SS wrote this paper.

Funding The authors have not declared a specific grant for this research from any funding agency in the public, commercial or not-for-profit sectors.

Competing interests None declared. 
Patient consent for publication Obtained.

Provenance and peer review Not commissioned; externally peer reviewed.

Open access This is an open access article distributed in accordance with the Creative Commons Attribution Non Commercial (CC BY-NC 4.0) license, which permits others to distribute, remix, adapt, build upon this work non-commercially, and license their derivative works on different terms, provided the original work is properly cited and the use is non-commercial. See: http://creativecommons.org/ licenses/by-nc/4.0/.

\section{REFERENCES}

1 Wahner-Roedler DL, Kyle RA. Heavy chain diseases. Best Pract Res Clin Haematol 2005:18:729-46.

2 Franklin EC, Lowenstein J, Bigelow B, et al. Heavy chain disease- a new disorder of serum gamma-globulins : report of the first case. Am J Med 1964;37:332-50.

3 Cook JR, Harris NL, Isaacson PG, et al. Heavy chain diseases; who classification of tumours of haematopoietic and lymphoid tissues, world Health organization. 4 edn. France: International Agency for Research on Cancer, 2017: 237-40.

4 Bianchi G, Anderson $\mathrm{KC}$, Harris NL, et al. The heavy chain diseases: clinical and pathologic features. Oncology 2014;28:45-53.

5 Wahner-Roedler DL, Witzig TE, Loehrer LL, et al. Gamma-heavy chain disease: review of 23 cases. Medicine 2003;82:236-50.

6 Fermand JP, Brouet JC, Danon F, et al. Gamma heavy chain "disease": heterogeneity of the clinicopathologic features. Report of 16 cases and review of the literature. Medicine 1989;68:321-35.
7 Simonneau G, Gatzoulis MA, Adatia I, et al. Updated clinical classification of pulmonary hypertension. J Am Coll Cardiol 2013;62:D34-41.

8 Mathew R, Huang J, Wu JM, et al. Hematological disorders and pulmonary hypertension. World I Cardiol 2016;8:703-18.

9 Morris CR, Gladwin MT, Kato GJ. Nitric oxide and arginine dysregulation: a novel pathway to pulmonary hypertension in hemolytic disorders. Curr Mol Med 2008:8:620-32.

10 Yan L, Chen X, Talati M, et al. Bone marrow-derived cells contribute to the pathogenesis of pulmonary arterial hypertension. Am J Respir Crit Care Med 2016;193:898-909.

11 Krishnan U, Mark TM, Niesvizky R, et al. Pulmonary hypertension complicating multiple myeloma. Pulm Circ 2015;5:590-7.

12 Hashimoto H, Kurata A, Mizuno H, et al. Pulmonary arterial hypertension due to pulmonary vascular amyloid deposition in a patient with multiple myeloma. Int I Clin Exp Pathol 2015;8:15391-5.

13 Munshi NC, Digumarthy S, Rahemtullah A. Case records of the Massachusetts General Hospital. Case 13-2008. A 46-year-old man with rheumatoid arthritis and lymphadenopathy. N Engl J Med 2008;358:1838-48.

14 Takano H, Nagata K, Mikoshiba M, et al. Combination of rituximab and chemotherapy showing anti-tumor effect in gamma heavy chain disease expressing CD20. Am J Hematol 2008;83:938-9.

15 Arnason JE, Mendez LM. Induction therapy for gamma-heavy chain disease with bortezomib and dexamethasone: a case report. Blood 2012;120:5051.

16 Garciaz S, Coso D, Schiano de Colella J-M, et al. Lenalidomide for the treatment of B-cell lymphoma. Expert Opin Investig Drugs 2016;25:1103-16.

Copyright 2020 BMJ Publishing Group. All rights reserved. For permission to reuse any of this content visit

https://www.bmj.com/company/products-services/rights-and-licensing/permissions/

BMJ Case Report Fellows may re-use this article for personal use and teaching without any further permission.

Become a Fellow of BMJ Case Reports today and you can:

- Submit as many cases as you like

- Enjoy fast sympathetic peer review and rapid publication of accepted articles

- Access all the published articles

- Re-use any of the published material for personal use and teaching without further permission

\section{Customer Service}

If you have any further queries about your subscription, please contact our customer services team on +44 (0) 2071111105 or via email at support@bmj.com.

Visit casereports.bmj.com for more articles like this and to become a Fellow 